\title{
INDIVIDUALIZATION OF RISKS DIAGNOSTICS IN ASSESSMENT OF INVESTMENT POTENTIAL OF SECTORAL COMPANIES IN DEVELOPING COUNTRIES
}

\author{
G. CHEBOTAREVA \\ Academic department of energy and industrial enterprises management system, Ural Federal University, Russia.
}

\begin{abstract}
Maintaining of the high level of investment potential of sectoral companies in developing countries, along with their sustainable development, constitutes an area of paramount importance of such companies' activity, particularly in the situation of global economic instability and mounting competitive pressure. In its turn, the development of the investment potential of a sectoral company aimed at improving its investment attractiveness necessitates the development of specific methodological tools allowing for a comprehensive approach to the issues of estimation of the existing uncertainty as well as unbiased diagnostics of risks affecting the operating efficiency of a company. The present paper describes an original method of individualized diagnostic approach to the risks of a sectoral company and assessment of the level of risks to investment potential. The practical aspects of risk assessment are discussed using a power-generating company as an example. The requirements for a modern risk management system of sectoral companies in developing countries were suggested as principles to be used in the course of the conducted study.

Keywords: Bayesian treatment, developing countries, efficiency, individualization of assessment, investment attractiveness, investment potential, power-generating company, risk management, risks diagnostics, sectoral company.
\end{abstract}

\section{INTRODUCTION}

The process of development of the investment potential of a sectoral company presents a complex and multi-level system of interrelated elements: stakeholders, tools and processes ensuring successive and sustainable development [1]. Among the factors contributing to the activation of the above process, e.g. in the power-generating sector, special mention should be made of:

1. Power demand.

2. Quality and security of power supply.

3. Power generation cost optimization.

4. Investors' objectives.

5. Availability of resources etc.

The factor exerting the greatest influence on investment potential is understood to be the level of risks which, in case of a complete or partial default, may result in deterioration of the competitive positions of a sectoral company in the market and loss in reliability and quality of the delivered services. 
The step-by-step sector development necessitates creation of an efficient system of investment potential assessment by way of on-line and comprehensive risks diagnostics [2-4]. This made the authors address the vital problem of developing methodological tools to allow comprehensive analysis of the risks of a sectoral company while maintaining the objectivity of the conclusions drawn.

The result of the investigation done is the development of an original methodological approach ensuring individual diagnostics of each risk. It was tested in the case of a powergenerating company. Besides, requirements were formulated to a modern system of risk management of sectoral companies in developing countries. The obtained results are of considerable practical importance and find application in the development of new methodologies to be employed in risk assessment of power-generating companies.

\section{MODERN PROBLEMS OF RISK DIAGNOSTICS OF SECTORAL COMPANIES IN DEVELOPING COUNTRIES}

As a rule, the system of risk management in sectoral companies in developing countries is characterized by lack of own unique system of risk management [2].

A series of analytical studies [5, 6] has revealed the most topical problems in the risk management system of sectoral companies in developing countries. For example, the most significant of these is that $83 \%$ of companies do not have in place a documented policy for sectoral risk management. At the same time, the industry risk-management system is characterized by several specific features, such as $[2,5]$ :

1. Subjectivity in the assessment of sectoral risks due to priority being given to qualitative approaches;

2. Absence of specialized organs capable of realizing a comprehensive risk management system;

3. Sectoral risks management orientation to financial profit for the period, instead of to equity or book value;

4. Limited resort to the hedging scheme as a risk management tool;

5. Limited use of professional market models etc. in forecasting.

The incomplete list of problems, however, corroborates the low level of modern development of risk management system in sectoral companies in developing countries. Thus, the main goal or research becomes the development of a methodological tool for diagnostics of individual risks of sectoral companies in developing countries and the determination of the main prospects for improvement in the above area.

\section{METHODOLOGICAL APPROACH TO INDIVIDUAL RISKS DIAGNOSTICS OF SECTORAL COMPANIES}

An important role in the assessment of the investment potential of a sectoral company belongs to the definition of individual risk state variation thresholds which, if exceeded, bring about development of negative processes. Analysis and estimate of the named thresholds are based on analysis of statistical data for each risk. Hence, it is also important in making an assessment to take into account the factors characterizing both retrospect and current risk status. This affords an opportunity to establish on an ongoing basis the causes of loss of investment potential of a sectoral company.

The stages of individual risks assessment of sectoral companies are illustrated in Fig. 1. 


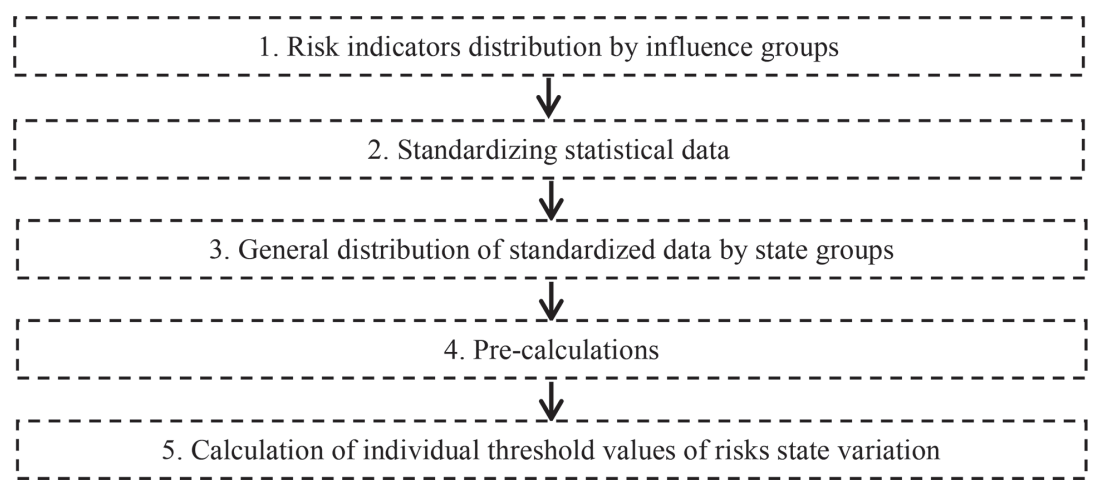

Figure 1: Stages of individual diagnostics of sectoral companies' risks.

\subsection{Standardization of risk indicators by influential groups}

Risk indicators distribution of influential groups envisages identification of the direct (DDI) and inverse (IDI) dependence indicators characterized by a universally oriented tendency and an oppositely directed dependence between indicator variations and level of risk respectively.

The need for such stage is determined by the requirement of subsequent risk indicators standardization: reduction to general comparability of multidimensional values in view of existence of "distance in a multidimensional space" [7].

In the first case, for DDI, eqn (1) is used [7, 8]:

$$
X_{j}^{N}=\frac{X_{j}-X_{\min }}{X_{\max }-X_{\min }}
$$

where $X_{j}^{N}$ - standardized value of actual $j$-th risk level, $X_{j}$ - actual $j$-th risk level, $X_{\min }$ minimum $j$ - th risk level, $X_{\max }$ - maximum $j$ - th risk level.

For IDI, standardization is carried out using eqn (2):

$$
X_{j}^{N}=\frac{X_{\max }-X_{j}}{X_{\max }-X_{\min }}
$$

\subsection{Preliminary risk assessment by state groups}

General distribution of standardized risk data is carried out by four state groups: minimum, tolerable, high and critical risk influence levels (RIL) [9].

The principal law of standardized risk value distribution of state groups implies expansion of the risk influence with an increase in the value of its determinant indicator.

The process of pre-calculation for obtaining a final estimate of state variation threshold values for each risk includes calculation of the following indicators:

1. Mathematical expectation $\left(M_{i}\right)$ for each risk in each of its states to define the mathematical expectation unit vectors for each state.

2. Unit vectors of difference between each risk value in each state and its respective mathematical expectation $\left(\mathrm{X}_{\mathrm{j}}-\mathrm{M}_{\mathrm{i}}\right)$, and their transposed values. 
3. Covariance matrices for each risk state using eqn (3).

$$
S_{i}=\frac{1}{n-1} * \sum_{i=1}^{n}\left(X_{n}-M_{i}\right) *\left(X_{n}-M_{i}\right)^{T}
$$

where $S_{i}$ - covariance matrix of $\mathrm{i}$-th risk state.

4. Reciprocal covariance matrices for each risk state.

5. Sums of reciprocal matrices of threshold states.

6. Determinants of covariance matrices for each risk state.

7. Unit vectors of differences between mathematical expectations for risk threshold states and their transposed values.

\subsection{Individual risk state diagnostics based on Bayesian treatment}

The overall assessment of each risk state of a sectoral company is carried out using eqn (4) based on Bayesian treatment, the essence of which consists in that "for a set of objects following the normal distribution law, the object with $\mathrm{X}$ parameters shall be related to set" $[2,7]$ :

$$
\begin{aligned}
& \ln \left(c_{i} q_{i}\right)-0.5 *\left(\left(X-M_{i}\right)^{T} * S_{i}^{-1} *\left(X-M_{i}\right)-\ln \left|S_{i}\right|\right)-\left(\ln \left(c_{i+1} q_{i+1}\right)-0.5 *\right. \\
& \left.\left(X-M_{i+1}\right)^{T} * S_{i+1}^{-1} *\left(X-M_{i+1}\right)-\ln \left|S_{i+1}\right|\right)
\end{aligned}
$$

where $X$ - vector of variables in the space of risks under study; $M_{i}, M_{i+1}$ - mathematical expectations; $S_{i}, S_{i+1}$ - covariance matrices; $q_{i}, q_{i+1}$ - priori probabilities of appearance of objects from i-th, $(i+1)$-th classes; $q_{i}, q_{i+1}$-margins of error in relating of objects to $i$-th, $(i+1)$-th classes.

Ultimately the obtained results may be used in deriving general rating indices of risks under study, also in the processes of graphic interpretation and calculation of cumulative risk [10].

\section{PRACTICAL APPLICATION OF APPROACH BY EXAMPLE OF RUSSIAN POWER-GENERATING COMPANY “T PLUS GROUP”}

Practical application of the methodological tools presented in paragraph 3 was illustrated by the example of a business enterprise in the Urals region, the Russian power-generating company “T Plus Group” (before 2015, “TGK-9” JSC).

\subsection{Brief characteristics of sectoral company risks}

As an example of individual diagnostics of sectoral company risks, four types of risk characterized by the following indicators were considered:

1. The share of imported equipment in the company: a company endogenous risk determined by its reliance on equipment of foreign manufacture which implies expenditures in the future periods on technical asset maintenance, including at the expense of adverse exchange differences. 
2. Amount of investment in company capital: an endogenous risk characterizing degradation of company's capability to ensure its technical and technological development in strategic perspective.

3. Per capita demand for resources in the region of company's location: an endogenous risk reflecting lessening of additional demand for power resources in the region, and, by extension, for construction of new power generating facilities.

4. The average cost of loans in the region: an exogenous risk of growth of premium for borrowing funds allocated for the purchase of raw materials and technology renewal.

\subsection{Individual diagnostics of risk status of sectoral company}

Individual diagnostics of the risk status of a sectoral company are carried out with reference to the company's reporting data characterizing the current and retrospect values of the indicators under study, as well as to the statistical data of the region.

As is shown in Table 1, based on the results of calculations performed, the following individual thresholds of variation for each risk state were obtained.

Comparison of the obtained individual thresholds and actual values of each risk as of 2015, as shown in Table 2, allows for accurate definition of the severity level of each risk affecting the investment potential of the public sectoral company "T Plus Group".

Thus, individual diagnostics of actual risk status allows the severity level to be defined for each risk affecting the investment potential of the sectoral company.

The Minimum influence level was demonstrated by the risk related to decrease in the amount of investment to company capital: its actual value of 0.05 c.u. falls within the value group of 0 to $0.3084 \mathrm{c}$.u. In practice, such risk indicator value is explained by the fact that on a length of 12 years the "T Plus Group" public company has been showing steady growth in capital investments.

Table 1: Individual thresholds of variation of risk status of sectoral company.

\begin{tabular}{|c|c|c|c|c|c|}
\hline \multirow[b]{2}{*}{ No } & \multirow[b]{2}{*}{ Designation } & \multirow[t]{2}{*}{ Risk states } & \multicolumn{3}{|c|}{$\begin{array}{l}\text { Numerical threshold values separat- } \\
\text { ing risk states, c.u. (deg., grad.) }\end{array}$} \\
\hline & & & $\begin{array}{c}\text { Minimum- } \\
\text { Tolerable } \\
\text { RIL }\end{array}$ & $\begin{array}{l}\text { Tolerable- } \\
\text { High RIL }\end{array}$ & $\begin{array}{l}\text { High- } \\
\text { Critical RIL }\end{array}$ \\
\hline 1. & $X_{1}^{N}$ & $\begin{array}{l}\text { Share of imported } \\
\text { equipment in company }\end{array}$ & $\begin{array}{l}0.1882 \\
(16.94)\end{array}$ & $\begin{array}{l}0.4898 \\
(44.08)\end{array}$ & $\begin{array}{l}0.8246 \\
(74.21)\end{array}$ \\
\hline 2. & $X_{2}^{N}$ & $\begin{array}{l}\text { Amount of investment in } \\
\text { company capital }\end{array}$ & $\begin{array}{l}0.3084 \\
(27.76)\end{array}$ & $\begin{array}{l}0.7079 \\
(63.71)\end{array}$ & $\begin{array}{l}0.9234 \\
(83.11)\end{array}$ \\
\hline 3. & $X_{3}^{N}$ & $\begin{array}{l}\text { Per capita demand for } \\
\text { resources in region }\end{array}$ & $\begin{array}{l}0.1757 \\
(15.81)\end{array}$ & $\begin{array}{l}0.5551 \\
(49.59)\end{array}$ & $\begin{array}{l}0.8207 \\
(73.86)\end{array}$ \\
\hline 4. & $X_{4}^{N}$ & $\begin{array}{l}\text { Average cost of loans in } \\
\text { region }\end{array}$ & $\begin{array}{l}0.0950 \\
(8.55)\end{array}$ & $\begin{array}{l}0.2620 \\
(23.58)\end{array}$ & $\begin{array}{l}0.4830 \\
(43.47)\end{array}$ \\
\hline
\end{tabular}


Table 2: Actual risk status of sectoral company.

\begin{tabular}{lllcl}
\hline No & Designation & \multicolumn{1}{c}{$\begin{array}{c}\text { Risk assessment indicator } \\
\text { name }\end{array}$} & $\begin{array}{c}\text { Standardized risk } \\
\text { value, c.u. (grad.) }\end{array}$ & $\begin{array}{c}\text { Risk state } \\
\text { characteristic }\end{array}$ \\
\hline 1. & $X_{1}^{N}$ & $\begin{array}{l}\text { Share of imported } \\
\text { equipment in company }\end{array}$ & $\begin{array}{c}\rightarrow 1.00 \\
(\rightarrow 90.00)\end{array}$ & Critical RIL \\
& & Amount of investment in & 0.05 & Minimum RIL \\
2. & $X_{2}^{N}$ & company capital & $(4.50)$ & High RIL \\
& & Per capita demand for & 0.72 & \\
3. & $X_{3}^{N}$ & resources in region & $(64.80)$ & Tolerable RIL \\
& & Average cost of loans in & 0.12 & $(10.80)$ \\
\hline
\end{tabular}

The reciprocal value is Critical, i.e. the maximum possible level of influence on investment potential of a sectoral company is exerted by the risk characterizing increase in the share of equipment of foreign manufacture in the overall volume of equipment use. The indicator tending towards the maximum value of 1.00 c.u. unambiguously relates it to the last group of influence.

Risks related to variations of per capita demand for power resources in the region, also those connected with an increase in the cost of loans fall within the medium range of values and are described as High and Tolerable influence levels, respectively.

The graphic interpretation of the obtained results is shown in Fig. 2.

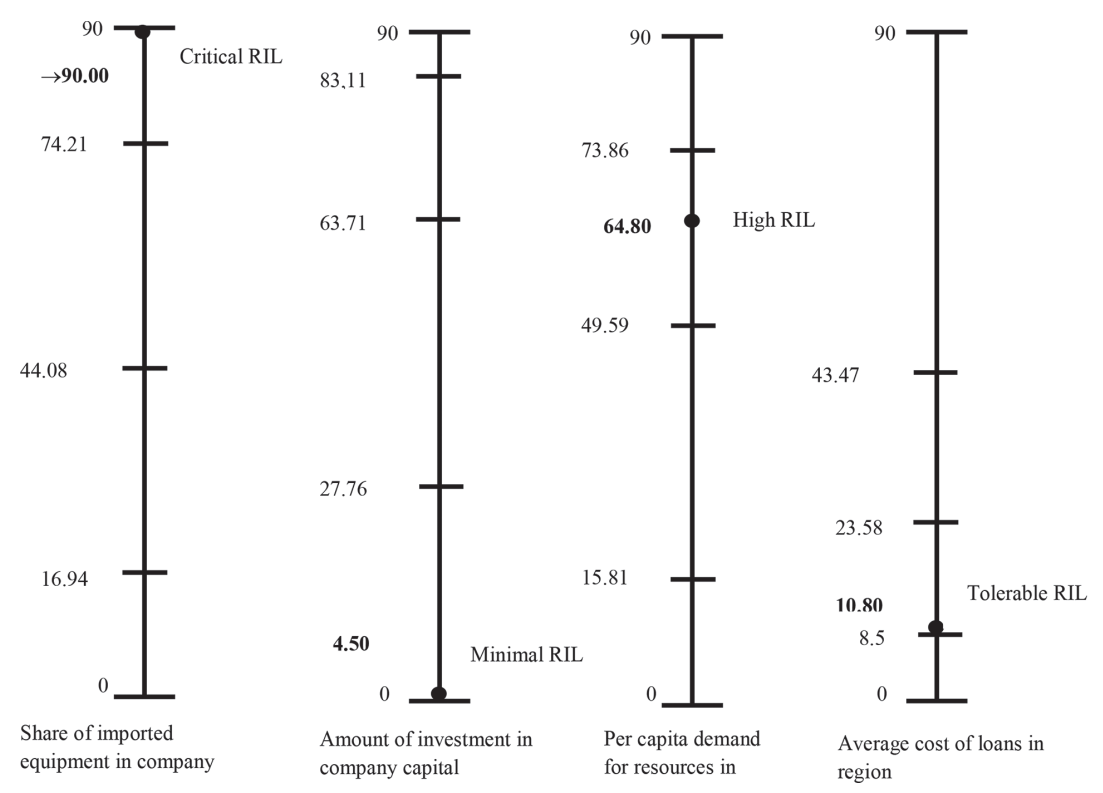

Figure 2: Graphic interpretation of the obtained results. 


\section{PROSPECTS FOR DEVELOPMENT OF ASSESSMENT OF INVESTMENT POTENTIAL OF SECTORAL COMPANIES IN DEVELOPING COUNTRIES}

The methodological approach to sectoral company individual risks assessment presented in this paper may find application in comprehensive assessment of the investment potential through a system of existing risks. Its application is particularly justified in the situation of observed influence of a considerable (10-15 and over) number of risks.

Among the major achievements of the presented methodological tools the following are worth special mentioning:

1. Individual approach to assessment of actual state of each risk.

2. Further risks rating by level of their influence on investment potential.

3. Risks ranking within each influence group based on estimation of risk relative value.

4. Original graphic interpretation and cumulative risk calculation.

5. As a result, more unbiased assessment of risks influence on investment potential of a sectoral company etc.

5.1 Up-to-date requirements to system of sectoral companies' risks diagnostics in developing countries

In the course of analysis of alternative approaches to assessment of risks of sectoral companies presented in a number of research papers $[2,11]$, made with account for the tendency towards individualization of risks diagnostics, and study of the actual risk management system situation in developing countries, the following practical and methodological principles/ requirements to modern system of sectoral risks management have been formulated:

1. Assessment methodology must combine both qualitative and quantitative analysis components, with prioritized quantitative approaches ("You can only manage what you can measure");

2. Assessment always bears a subjectivity factor. It is therefore important to minimize its value in the assessment. Reduction of the role of expert opinion should take place through the development and application of respective mathematical tools;

3. Comprehensive approach to assessment of investment attractiveness which envisages taking into account both the exogenous and endogenous activity factors of a power-generating company, including indicators of its financial and market standing;

4. Specification of used methodological approaches with due consideration for sectoral and regional specificity in the study of investment attractiveness of a power-generating company;

5. Continual improvement of the mechanism of diagnostics of risks and assessment of investment potential.

\section{CONCLUSIONS}

The global economic system development instability and mounting competitive pressure on the world markets bring forth the problem of improving the system of risks diagnostics, in the first place, for sectoral companies of developing countries.

The conducted analysis and the obtained results allowed the most critical aspects to be highlighted in the activities of a sectoral company, with the "T Plus Group" public company 
taken as an example: such are the risks most strongly affecting the level of the company's investment potential. Among them are the risks related to use by company of imported equipment and decrease in the per capita demand for power resources in the region.

Achieving the specified goal was rendered possible through application of the methodological tool including the stages of calculation of risk states variation thresholds, assessment of each risk actual value, and risks ranking by influence level groups.

In its turn, definition of growth areas dictates the need for dynamic response to the current situation to promptly neutralize the negative tendencies and assess the efficiency of respective risk mitigation programs. Such approach will in the future necessitate putting together the scenarios of development of sectoral company's investment potential. From the practical point of view, with expansion of risks sampling size, the promising directions are found to be general risks rating and graphic interpretation, and calculation of the actual value of cumulative risk.

\section{ACKNOWLEDGEMENT}

The work was supported with a grant of the Russian Science Foundation (project No 1778-10039).

\section{REFERENCES}

[1] Domnikov, A., Chebotareva, G. \& Khodorovsky, M., Increase the objectivity of the investment risks assessment of power-generating companies: rating approach. Vestnik UrFU, 4, pp. 87-97, 2014.

[2] Domnikov, A., Chebotareva, G. \& Khodorovsky, M., Development of risk management for power generating companies in developing countries. WIT Transactions on Ecology and the Environment, 193, pp. 859-870, 2015. http://dx.doi.org/10.2495/SDP150721

[3] Gorby, M.B., A risk-factor model foundation for rating-based bank capital rules. Journal of Financial Intermediation, 25, pp. 199-232, 2003.

[4] Vasicek, O., Loan portfolio value. Credit Portfolio Models, 15, pp. 160-162, 2002.

[5] Domnikov, A., Khomenko, P. \& Chebotareva, G., A risk-oriented approach to capital management at a power generation company in Russia. WIT Transactions on Ecology and the Environment, 186, pp. 13-24, 2014.

http://dx.doi.org/10.2495/ESUS140021

[6] Market Risk Management in Russian electricity companies. Analytical study; KPMG, 2012, available at: https://www.kpmg.com/RU/en/IssuesAndInsights/Articles Publications/Documents/Market-risk-management-at-Russian-power-companies -eng.pdf

[7] Domnikov, A., Competitive development of cogeneration systems of energy. Ural State Technical University, pp. 54-55, 2008.

[8] Tatarkin, A., The complex technique of energy security diagnostics of territorial entities of the Russian Federation. Economy Institute, pp. 56-56, 2002.

[9] Khodorovsky, M., Domnikov, A. \& Chebotareva, G., Classification of investor attractiveness risks in high-precision industries: a qualitative aspects (by example of electricity). Vestnik SUSU, 2, pp. 99-106, 2014. 
[10] Domnikov, A., Chebotareva, G. \& Khodorovsky, M., Evaluation of investor attractiveness of power-generating companies: special reference to the development risks of the electric power industry. WIT Transactions on Ecology and the Environment, 190(1), pp. 199-210, 2014.

http://dx.doi.org/10.2495/EQ140211

[11] Merton, R.C., On the pricing of Corporate debt: The risk structure of interest rates. Journal of Finance, 29, pp. 449-470, 1974.

http://dx.doi.org/10.1111/j.1540-6261.1974.tb03058.x 